\title{
Antinuclear Antibody Measurement
}

National Cancer Institute

\section{Source}

National Cancer Institute. Antinuclear Antibody Measurement. NCI Thesaurus. Code C74916.

The determination of the amount of antinuclear antibodies present in a sample. 